coast and in the Skager Rack and Cattegat. One was taken in 42 fathoms east of Coquet Island, April 30, 1937.

Centrolophus niger (Gmelin). The black-fish of Couch is considered a fish of the Mediterranean and Atlantic. Occasional stragglers have been taken off our south coast and Day refers to specimens from the Northumberland and Yorkshire coasts. One of $56 \mathrm{~cm}$. was taken on Berwick Bank, October 25, 1937.

Cetorhinus maximus (Gunner). It is generally supposed that the basking shark migrates northwards along the Atlantic seaboard as far as the Norwegian coast after its appearance off the west coast of Ireland in spring. Occasionally it enters the North Sea. One, $10 \mathrm{ft} .11 \frac{1}{2} \mathrm{in}$. in length, was caught in salmon nets, 2 miles off Souter, on June 13, 1934 .
Ctenolabrus rupestris (L.). The goldsinny is found along the Atlantic coasts of Europe from the Mediterranean to Trondheim and in the southern Baltic. It has been recorded for Northumberland and Yorkshire, but not in our time. A specimen caught on July 3, 1935, 20 miles north-north-east of the Tyne, is living in the aquarium. Another was picked up on Whitley sands, January 31, 1937.

Maurolicus muelleri (Gmelin). The pearl-side has a wide distribution. According to Smitt, it has been found on both sides of the Atlantic and from the coast of Finmark to that of Sweden. It also enters the North Sea. It is far from common off our coast. Three specimens have been picked up on the sands of Cullercoats and Whitley Bay recently in March and April; one in 1936 and two in 1937.

\title{
Science and Industry
}

\begin{abstract}
A SERIES of lectures arranged by the London B Branch of the Association of Scientific Workers on the subject of science and industry has recently come to its conclusion. These lectures were arranged by the Association with the object of directing attention to the application of scientific methods and developments in industry, and the possibility of increased application; the allied question of the organization of research; and the question of the best types of scientific education to fit men for technical positions in industry.

The first lecture was given by Sir Richard Gregory. $\mathrm{He}$ opened with an enumeration of some of the outstanding benefits that science has conferred on society, and showed how the developments of industry have depended upon the developments of creative science. The extent, however, to which scientific discovery is used for industrial progress depends upon the capacity of industry to understand the results of research and the power to use them. The general principle that expenditure on science is a profitable investment may be said to have been conceded, but as yet science is not used as fully as it may be. Forty years ago the expenditure of the British Government on scientific investigation was about $£ 45,000$; at the present time the total amount is nearly two millions, of which the Department of Scientific and Industrial Research administers about $£ 600,000$. Sir Richard quoted a memorandum presented by the Parliamentary Science Committee, and supported its argument that the provision for scientific and industrial research in Great Britain is inadequate and that a bolder and broader financial scheme is needed.
\end{abstract}

Sir Richard went on to plead for the employment of men with scientific training and knowledge as directors and administrators. Industry suffers from administ ators who have not a scientific outlook and do not realize the value of long-sustained expenditure on scientific research, although he admitted that it is difficult to find men who combine specialized know. ledge on scientific and technical subjects with organizing or administrative capacity.

Sir John Russell traced the application of science to agriculture from the early investigation into artificial manures carried out on the same land now occupied by the Experimental Station at Rothamsted to the present day, when such research demands the knowledge of chemists, physicists, botanists, biochemists, pathologists, etc. The development of agriculture has not been devoid of chance discoveries, particularly in the development of wheat and in the use of such things as Bordeaux mixture, devised to scare away predatory boys. There has, however, been great advances in the knowledge and control of the processes of Nature as a result of the patient detailed work that has been carried out. Besides the effect of the well-known artificial manures, it has been discovered of recent years that traces of certain inorganic salts such as the compounds of cobalt and boron have a marked effect on the plant life and the subsistent animal life.

Under the title of "Science in the Chemical Industry", Major F. A. Freeth indulged in alternate attacks on and justification of the existence of industrial scientific workers. The attacks were, however, more of the nature of constructive criticism. That the existence of men of science is justified there is no doubt; but there is doubt whether they have the right attitude to their tasks. Men of science as a body lack rhetoric-they do not know how to capture the enthusiasm of the general public.

The chemical industry itself is the only industry that takes its name from the science on which it is based. It should properly be called the 'molecular industry', for it is chiefly the scientific study of the behaviour of molecules which forms the basis on which the large industries are built. Some of the heavy chemical industries date back for decades, but the modern organic chemist owes everything to the patient hard work of investigators which is continuing all the time. Fundamental scientific theory is required for any new development in the chemical industry, but before it can be put into practice it must be translated into terms of large-scale plant and teams of men, and there is often a considerable timelag between the adoption of a new method and its achievement in practice.

Dr. E. A. Rudge spoke on the subject of training for the chemical industry and chemical engineering; and described an investigation he had conducted to find out the requirements of a number of chemical 
industries by way of recruits to their scientific staffs. With the great increase in scientific control in industry there has arisen a demand for a varied army of scientific workers, ranging from routine semiskilled testers to fully trained research specialists. By means of a questionnaire Dr. Rudge has gained information that shows the distribution of the demand for scientific workers in the different grades.

This investigation produced the following main conclusions. A large proportion of the chemical firms in the area investigated employ small laboratory personnel (less than ten employees). These small organizations commonly employ unqualified recruits, and it is in the main the larger laboratories that require graduates and research workers. A great preference is shown for recruits of about matriculation standard with a knowledge of industrial method and technique. For every graduate required for the specialized work of research development more than nine undergraduates are required for laboratory routine. The question of the training of these un- qualified employees is one that requires greater cooperation between industry and teachers, especially in the technical colleges.

Dr. F. S. Sinnatt, speaking on the Fuel Research Coal Survey, said that the work of the Department of Scientific and Industrial Research can be divided into two sections: the utilization of coal, and the survey of the coalfields of Great Britain. Different types of coal are needed for use in coking, gas manufacture, steam raising, household use and hydrogenation; wide variation may occur in the composition of a seam within the area covered by one mine, with consequent changes in its suitability for these different purposes. The control of such variation is of primary importance to the consumer and must be the basis of any improvement in the utilization of coal.

As a result of the work already done, it can now be said about certain important seams in different coal. fields that every major variation in the composition is known, and that it can be forecast for any spot within narrow limits.

\section{The Waite Agricultural Research Institute, South Australia}

$\mathrm{T}$

HE Waite Agricultural Research Institute was established at Glen Osmond, near Adelaide, South Australia, in 1925, as a result of the late $\mathrm{Mr}$. Peter Waite's gift to the University of Adelaide for the purpose of furthering the cause of education and research in agriculture and allied subjects. The total value of the bequest was estimated at $£ 100,000$.

The University Council decided that the prineipal objective of the Institute should be to enlarge the stock of knowledge relating to agriculture in the widest sense, and pass it on to those actively engaged in production, as farmers or pastoralists. Two chairs were established: one in agriculture and one in agricultural chemistry. Prof. A. E. V. Richardson was appointed Waite professor of agriculture and first director of the Waite Institute; Prof. J. A. Prescott was appointed Waite professor of agricultural chemistry. Since the commencement of active work early in 1925, the number of research workers stationed at the Institute has risen from five to forty, and the annual income from $£ 8,000$ to approximately $£ 25,000$, apart from a yearly grant by the Australian Commonwealth Council for Scientific and Industrial Research for the maintenance of its Division of Soils, which has its headquarters at the Waite Institute. After thirteen years of eminent service, Prof. Richardson has now resigned to occupy the position of Deputy Chief Executive Officer of the Council for Scientific and Industrial Research, and Prof. Prescott has been appointed director of the Waite Institute.

Prof. Richardson is a graduate of the University of Adelaide and was acting director of agriculture in South Australia in 1911. From 1911 until 1924 he was superintendent of agriculture for Victoria and visited the United States and Canada to report on agricultural research and education in 1918. From 1919 until 1924 he was director of the School of Agriculture in the University of Melbourne. Prof. Richardson visited South Africa, Europe, America,
Japan and Java in 1926 and was a delegate to the Imperial Agricultural Research Conference at London in 1927. He was appointed a member of the Executive of the Australian Council for Scientific and Industrial Research in 1927, shortly after its inception in 1926, and was official agricultural adviser to the Australian delegation to the Imperial Conference at Ottawa in 1932. He was elected first president of the Australian Institute of Agricultural Science, which was established in 1935.

Prof. Prescott is a native of Lancashire and graduated in chemistry at the University of Manchester. In addition to post-graduate experience at Manchester, he worked at Rothamsted Experimental Station with Sir John Russell and at the University of Leipzig with Dr. Wolfgang Ostwald. From 1916 until 1923 he was chief chemist to the Royal Agricultural Society of Egypt and superintendent of field experiments at the Society's Experimental Farm at Bahtim. His work in Egypt concerned problems of soil fertility associated with Egyptian agriculture and the manuring, spacing and irrigation of wheat, maize and cotton.

In 1929, Prof. Prescott was appointed chief of the Division of Soils of the Council for Scientific and Industrial Research at the Waite Institute. His work in Australia has related chiefly to the classification and geographical distribution of soils, and his bulletin on the soils of Australia, published in 1931, has become a standard reference book throughout Australia. Prof. Prescott has travelled extensively in Australia and New Zealand and is familiar with agricultural and pastoral conditions in all the Australian States and the Northern Territory. $\mathrm{He}$ was federal president of the Australian Chemical Institute in 1936-37.

The association of Richardson and Prescott over the first thirteen years of the Waite Institute has proved of immense value to agricultural science in Australia. 